Available online on 15.03.2019 at http://jddtonline.info
Journal of Drug Delivery and Therapeutics
(C) 2011-18, publisher and licensee JDDT, This is an Open Access article which permits unrestricted
non-commercial use, provided the original work is properly cited

Open $\odot_{\text {Access }}$

Review Article

\title{
Stevia (Meethi Patti) as an alternative form of sugar
}

\author{
Ashaq Hussain Rather ${ }^{1 *}$, S. Singh ${ }^{1}$, Basharat Suhail2 ${ }^{2}$, Ghanshyam Patel ${ }^{3}$ \\ ${ }^{1}$ Algal Biotechnology Laboratory, Department of Post Graduate Studies and Research in Biological Science, Rani Durgavati University, Jabalpur- \\ 482001, (M.P.), India.
}

${ }^{2}$ Polymer Research Laboratory, Govt Science College, Jabalpur-482001, (M.P.), India.

${ }^{3}$ Rajiv Gandhi College of Pharmacy, Bhopal, (M.P.), India.

\begin{abstract}
Stevia rebaudiana (Bertoni) is a herb. Stevioside, non-caloric sweetener present in the leaves of Stevia are non-nutritive, non-toxic, high-potency sweeteners and being 300 times sweeter than sucrose may be alternate for sucrose as well as other synthetic sweeteners. This review summarizes history of Stevia, nutritional composition of Stevia, cultivation, industrial overview and biological applications.
\end{abstract}

Keywords: Stevia rebaudiana, Stevioside, Sweetener

Article Info: Received 20 Jan 2019; $\quad$ Review Completed 25 Feb 2019; Accepted 26 Feb 2019; Available online 15 March 2019

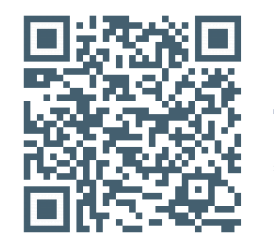

\section{Cite this article as:}

Rather AH, Singh S, Suhail B, Patel G, Stevia (Meethi Patti) as an alternative form of sugar, Journal of Drug Delivery and Therapeutics. 2019; 9(2):453-457 http://dx.doi.org/10.22270/jddt.v9i2.2503

\section{*Address for Correspondence:}

Science, Rani Durgavati University, Jabalpur-482001, (M.P.), India.

\section{INTRODUCTION}

Sugar and sweet consumption have been popular and intrinsic to Indian culture, traditions, and religion from ancient times. In the last couple of decades, people has been more concern about health and has become a daily routine to exercise, eat healthy food and decrease the consumption of food rich in sugar, salt and fat. Omission of added sucrose in foods increases the relative proportion of polymeric carbohydrates that may have beneficial effect for a balanced food intake as well as for human health ${ }^{1}$. In addition, there has been an increase in the demand by consumers for food with functional properties. Changes in eating habits and lifestyle are mainly due to incessant search for health ${ }^{2}$.

In the past, food science was concerned with the development of food for human survival, a goal that was substituted by the concept of production of quality food. More recently, the main concept has become to use food as a means of promoting health and welfare, while reducing the risk of disease. The food industry has responded to this demand and as a consequence, there has been a fast growing increase in diet foods and beverages available to consumers in many markets of the world. With increased consumer interest in reducing sugar intake, food products made with sweeteners rather than the sugar have become popular. Sweeteners are alternative substances to sugars, which give food a sweet taste and are used to partially or totally replace sucrose $^{3}$. The discovery of great number of sweeteners during the last decade has triggered the development of sugar free products, particularly for diabetic, obese people and for dietetic purpose. Two Sweeteners such as nutritive (Polyols) and nonnutritive/ intense sweeteners (Artificial and natural) have become alternatives to replace sucrose and have been widely used in various food products. Natural sweeteners are mainly plant constituents. Plants have contributed to about 75 highly sweet compounds. These sweet compounds fall mainly within the terpenoid, flavonoid and protein compound classes, although altogether nine districts structural groups of potently sweet molecules have been derived from plants ${ }^{4}$.

So far, highly sweet compounds have not been documented as these occurred in lower plants, insects or native organisms and the taxonomic distribution of plants, known to biosynthesize highly sweet compounds, is random within the angiosperm super order as classified according to Dahlgren. 


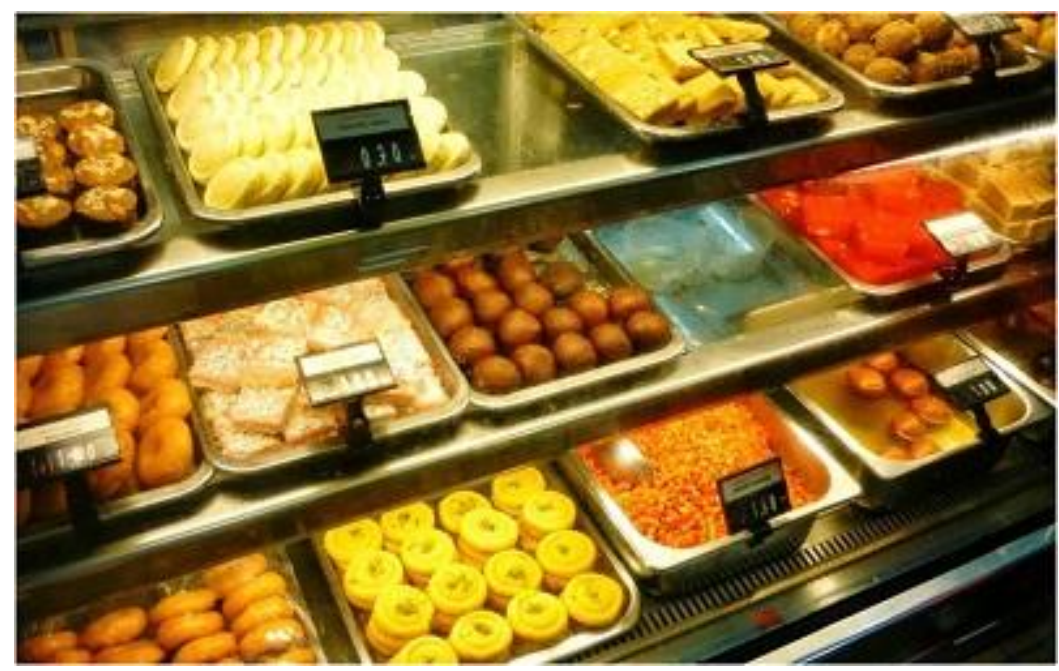

Figure 1: Different types of Indian sweets

\section{Classification of sweeteners}

\begin{tabular}{ll}
\hline & Sweeteners \\
- &
\end{tabular}

\section{HISTORY OF STEVIA}

Stevia leaves were used by indigenous peoples in Paraguay and Brazil since before recorded history ${ }^{5}$. In the 1887, M.S. Bertoni6, a botanist was first European to document Stevia and later on in 1931, French chemists extracted stevioside, the main sweet component in the form of an extremely sweet, white crystalline compound. Afterwards Stevia was considered to utilize as a sweetener for food shortage experienced by Britain during World War II, conversely, interest faded when sugar again became available. Japan used Stevia in place of succharin after it was banned in the 1970s and Stevia sweeteners have been consumed in Japan in large amount than in any other country.In North America and Europe, Stevia began to use as herbal product and started available in the market. In the 1970s and 1980s and its extracts have been allowed for using as a dietary enhancement in the US in 1994

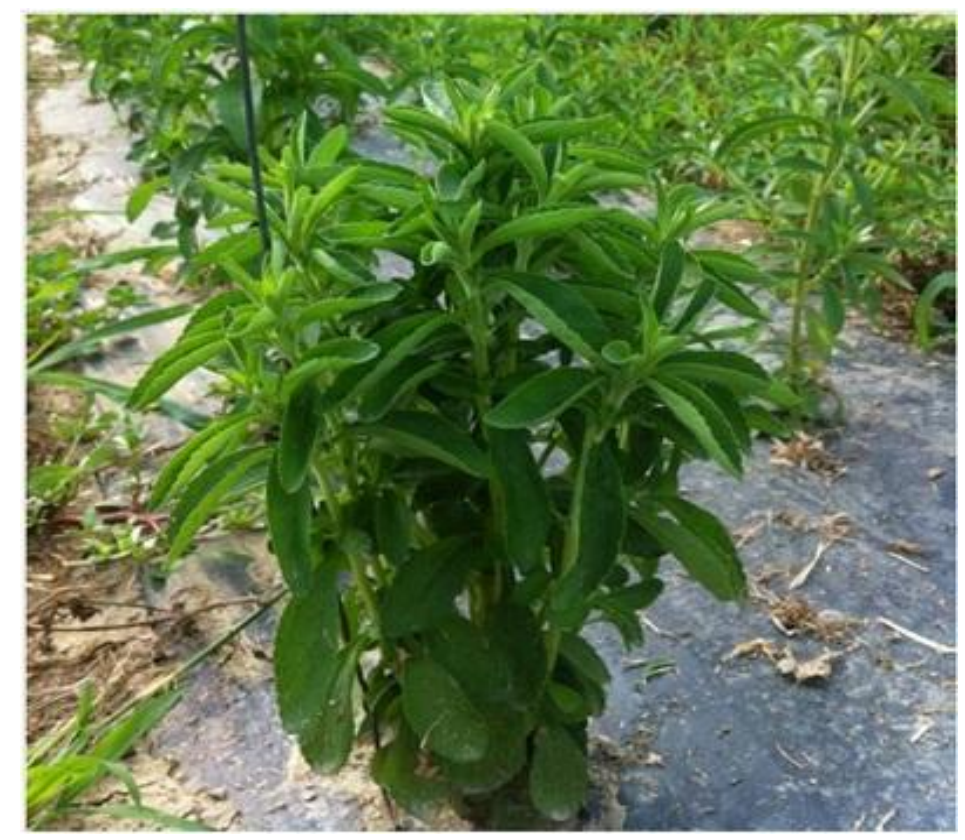

Figure 2: Field view of Stevia ${ }^{4}$ 


\section{CLASSIFICATION OF STEVIA}

Stevia rebaudiana is one of the 950 genera of the Asteraceae family 7 . A systematic classification was done on the North and Central American species of Stevia ${ }^{8}$. Stevia consists of a group of annual and perennial herbs, subshurbs and shrubs that occur in mountain regions, open forests, borders of rivers and dry valleys ${ }^{9}$. Its first botanical description is attributed to M. S. Bertoni. The plant was first called Eupatorium rebaudianum Bert. in honour of Rebaudi, the first chemist to study the chemical characteristics of the substances extracted. Its name was later changed to the current one, and it was recommended not only for food production, but also for the medicinal effects that were attributed to it. Although there are about 230 species in the genus, only $S$. rebaudiana gave the sweetest essence ${ }^{7}$.
Systematic Classification of $S$, rebaudiana ${ }^{8}$

Kingdom : Plantae

Division : Magnoliophyta

Class : Magnoliopsida

Subclass : Asteridae

Order : Asterales

Family : Asteraceae

Genus : Stevia

Species : rebaudiana

Table 1: Nutritional composition of Stevia ${ }^{10}$.

\begin{tabular}{|c|c|}
\hline & \multicolumn{2}{c|}{ Per 100 gm } \\
\hline Nutrient composition & Proximate \\
\hline Moisture(g) & $\mathbf{7}$ \\
\hline Energy(K cal) & $\mathbf{2 7 0}$ \\
\hline Protein(g) & $\mathbf{1 0}$ \\
\hline Fat(g) & $\mathbf{3}$ \\
\hline Total Carbohydrate(g) & $\mathbf{5 2}$ \\
\hline Ash(g) & $\mathbf{1 1}$ \\
\hline Crude fibre(g) & $\mathbf{1 8}$ \\
\hline Calcium(mg) & $\mathbf{4 6 4 . 4}$ \\
\hline Phosphorous(mg) & $\mathbf{1 1 . 4}$ \\
\hline Iron(mg) & $\mathbf{5 5 . 3}$ \\
\hline Sodium(mg & $\mathbf{1 9 0 . 0}$ \\
\hline Potassium(mg) & $\mathbf{1 8 0 0 . 0}$ \\
\hline Oxalic acid(mg) & 2295.0 \\
\hline Tannins(mg) & \\
\hline
\end{tabular}

\section{CULTIVATION OF STEVIA IN INDIA}

Stevia is self-incompatible in nature; hence propagation through seeds is a difficult proposition. Therefore, vegetative propagation or micro propagation is the means of propagation of Stevia. ${ }^{11}$ standardized the vegetative propagation technique using stem cuttings. The $15 \mathrm{~cm}$ length of cuttings was found to be optimum and pretreatment of cuttings with Paclobutrazol at 50-100 ppm resulted in good sprouting and rooting. ${ }^{12}$ standardized the micro propagation technique. Stevia can be grown on a wide range of soil with $\mathrm{pH}$ range from slightly acidic to neutral, but soil should not be saline. A field experiment was conducted at University of Agricultural Sciences, Bangalore to study the effect of length of stem cuttings and growth regulators on vegetative propagation of Stevia. The sprouting percentage and shoot growth of sprouted cuttings were significantly higher with $15 \mathrm{~cm}$ cuttings compared to $7.5 \mathrm{~cm}$ cuttings. Pretreatment of cuttings with 3-Indolbutyric acid (IBA) or naphthalene acetic acid (NAA) or their mixture caused injury to callus tissue due to higher concentration and resulted in very poor sprouting even compared to control. The direct planting of stem in main field was found to have a limited success. Two accessions of S.rebaudiana were successfully introduced in the experimental farm at the Institute of Himalayan Bioresource Technology (IHBT), Palampur in 2000.

Cultivation trial of these accessions was conducted during 2001-03.0verall crop performance was satisfactory for both

ISSN: 2250-1177 the accessions and they were least affected by biotic and abiotic factors like high rainfall, frost, and infestation by insects and disease. Quantitative differences were found in Stevioside content of the two accessions, ranging between 6 and 8\%. Accession 1 was superior in Stevioside content and Accession 2was superior in leaf biomass. Higher content of Stevioside was found in the regenerated crop in January, during the second year of plant growth. With improved management practices, there is further scope for improvement in Stevioside content. A laboratory-scale process was developed for the extraction of Stevioside up to $63 \%$ purity. Although the crop is self incompatible in its breeding behavior, the prevalence of two diverse accessions has facilitated seed production under Palampur conditions. This has triggered the production of plant material for its introduction amongst interested growers in large numbers.

\section{BIOLOGICAL PROPERTIES}

\section{Antioxidant property}

Stevioside, along with Steviolbioside, isosteviol and steviol caused inhibition of oxidative phosphorylation in rat liver mitochondria ${ }^{13}$. The effect of several natural products extracted from the leaves of $S$. rebaudiana on rat liver mitochandria was investigated. They inhibited oxidative phosphorylation including ATPase, NADH-oxidase, succinate-oxidase, succinate dehydrogenase and glutamate dehydrogenase activity. Leaf extracts of S.rebaudina promotes effect on certain physiological system such as the 
cordiovascular system and renal systems and influences hypertension and hyperglycemia. Hence these activities may be correlated with the presence of antioxidant compound, leaf and callus extracts of S. rebaudiana were evaluated for their total phenol, flavonoids content and total antioxidant capacity.

\section{Anti hyperglycemic effect}

Some metabolic syndrome such as diabetes which is caused due to the insulin abnormalities, pancreatic alpha cell dysfunction and comparative glucosan excess ${ }^{14}$ are the foremost public health anxiety in the present world. Stevia products (stevioside) could be admired as herbal or alternative medicine undoubtedly Stevia extracts have been extensively used for Diabates treatment in south America1. The hyperglycemic effect of Stevia leaves in equally high carbohydrate and high fat diets showed a significant reduction in blood glucose level at the subsequent 4 weeks of treatment to rats. Consequently, aqueous extract of Stevia leaves on glucose tolerance was also investigated and observed that ingestion of aqueous extract showed considerable decrease in plasma glucose level throughout glucose tolerance test ${ }^{15}$.Thus Stevia is a good natural source as an alternative of artificial Sugar.

\section{Anti-inflammatory and immunomodulatory activity}

Studies were carried out in elucidate the antiflammatory and immunomodulatory activities of stevioside and its metabolite, steviol. Stevioside at $1 \mathrm{Mm}$ significantly suppressed lipopolysaccharide (LPS) - induced release of TNF- $\alpha$ and IL-I $\beta$ and slighty suppressed nitric oxide release in THP-I cells without exerting any direct toxic effect, whereas steviol did not do so even at $100 \mathrm{um}$. Activation of IKKB and transcription factor NF-Kappa B were suppressed by stevioside, as demonstrated by western blotting furthermore only stevioside induced, TNF- $\alpha$, IL-1 $\beta$ and nitric oxide release in unstimulated THP- 1 cells. Release of TNF- $\alpha$ could be partially neutralized by anti TLR4 antibody. The study suggested that stevioside attenuates synthesis of inflammatory mediators in LPS-stimulated THP-I cells by interfering with the IKK beta and NF kappa B signaling pathway and stevioside-induced TNF- $\alpha$ secretion is partially mediated through TLR416.

\section{Effect on blood pressure}

The plant was found to possess vasodilatory action in both normal and hypertensive animals ${ }^{17}$. Stevia was previously been shown to reduce blood pressure in studies in animals. Stevia decreases in blood pressure and increase in diuretic and natriuretic affects in rats. ${ }^{18}$

\section{Antiviral activity}

S. rebaundina extracts are potent anti-rotavirus inhibitory invitro and invivo ${ }^{19}$. The inhibitory components of Stevia extract were found to be heterogenous anionic polysaccharide with different ion charges. The component analysis suggested that the purified fraction named as Stevian with the highest inhibitory activity consists of an anionic polysaccharide with molecular weight of 9800 containing the amino acids ser and Ala. Analysis of sugar residues suggest uronic acid as sugar component. It did not contain amino and neutral sugars and suphate residues.

\section{Industrial overview of Stevia}

The total market value of Stevia sweetener in Japan is estimated to be around 2-3 billion yen/yr. The crop has been introduced in other countries, including Brazil, Korea, Mexico, Indonesia and Tanzania ${ }^{20}$. Presently, more than 1300 MT raw material of Stevia is being cultivated in China, Taiwan and Malaysia for marketing in Japan. Keeping in view the Stevia's increasing popularity along with its traditional importance all over the world, India has also invested in the cultivation of Stevia. Department of AYUSH, Govt. of India has accepted a project for financing the Stevia cultivation in Uttaranchal, West Bengal, Haryana and Punjab.

Stevia's plant propagation and crop production studies were conducted in the Chandpur Experimental Field at the Institute of Himalayan Bioresource Technology (IHBT). Palampur located in Kangra Valley, Himachal Pradesh, India.

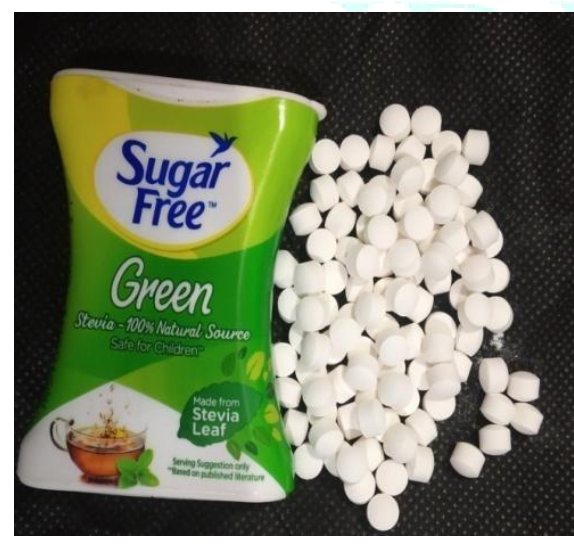

A

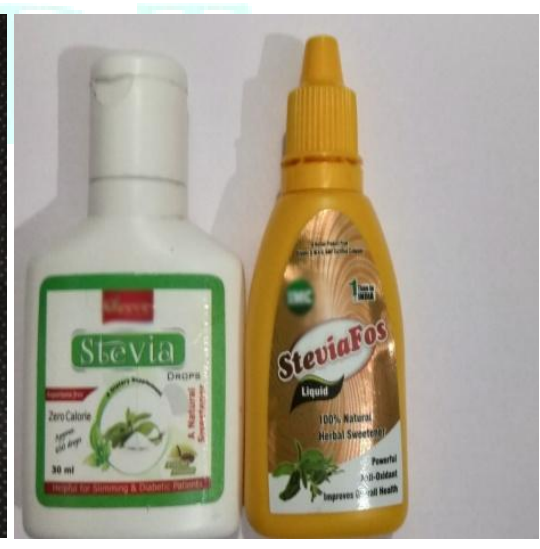

B

Figure 3: A. Stevia pellet form B. Stevia liquid form

\section{CONCLUSION}

Stevia rebaudiana Bertoni is an herb from South America that has found a upteem applications in the production of natural sweetener with emphasized sweetness. Due to its chemical structure and health-promoting phytochemical components, Stevia is suitable for the extraction and production of functional food ingredients. Also, Stevia is a good source of carbohydrates, proteins, dietary fibers, minerals, and amino acids. Future research should be focused on commercial production of Stevia based food products for human consumption.

\section{ACKNOWLEDGMENT}

We are thankful to Ms Rekha Rao for providing language help. 


\section{REFERENCES}

1. Kinghorn A.D. and Soejarto D.D. Current status of stevioside as a sweetening agent for human uses. Progress in Economic and Medical Plant Research 1985; 1:1-52.

2. Colombus M. The Cultivation of Stevia 'Nature's Sweetener.' Ontario Canada 1997; 4: 98.

3. Anonymous. Low calorie sweeteners and health. IFIC Review, Washington 2003; 1-12.

4. Lee.J.I. Studies on the New Sweetening Source Plant, Stevia Research Reports of the office of Rural Development Crop $1980 ; 22-22$.

5. Lee J.I. and Kang K.K. Studies on new sweetening resource plant Stevia (Stevia rebaudiana Bert.) in Korea, I, Effects of transplanting date shifting by cutting and seeding dates on gronomic characteristics and dry leaf yields of Stevia. Res Resp ORD 1979; 21:171-179.

6. Bertoni Avaliacao do efeito hipoglicemiante em coelhos aloxanizados. Ciencia Cultura 1977; 29:599-601.

7. Soejarto D.D., Nanyakkare N.P.D., Compadre C.M., Makapugay H.C., Hovance-Brown J.M., Medon P.J. and Kamth S.K. A phytochemnical screening procedure for sweetent-Kaurene glyscosides in the genus Stevia. J. Nat. Prod., 1984; 47:439-444.

8. Grashoff J. L. A systematic study of the North and Central American species of Stevia. University of Texas, Austin, TX 1972; pp 624.

9. Robinson R. L. Contributions from the Gray Herbarium of Harvard University XC, The Gray Herbarium of Harvard University, Cambridge, MA 1930 pp. 7891.

10. Savita S.M., Sheela K. and Sunanda S. Stevia rebaudiana- A functional Component for Food Industry. Journal of Human Ecology 2004; 15 (4): 261-264.

11. Chalapathi.M.V., Shivraj B., Ramakrishna P.V.R. Nutrient uptake and yield of Stevia (Stevia rebaudiana bertoni) as influenced by methods of planting and fertilizer levels. Crop Research 1997; 14(2):205-208.

12. Ashwini K. S. Production of multiple shoots and somatic embryogenesis in Stevia rebaudiana Bertoni through in vitro propagation. M.Sc. (Agri.) thesis, UAS, Bangalore, India 1996.

13. Kelmer B.A., Alvarez M. and Brancht A. Effects of Stevia rebaudiana natural products on rat liver mitochondria, Biochem Pharmacol 1985; 34:873-882.

14. Fronza D. and Folegatti M.V. Water consumption of the stevia (Stevia rebaudiana (Bert.) Bertoni) crop estimated through micro-lysimeter. Sci. Agric. 2003; 60:1518.

15. Curi R., Alzarez M., Bazotte R.B. Botion L.M., Godoy J.L. and Bracht A. Effect of Stevia rebaudiana on glucose tolerance in normal adult humans. Braz J Biol Res 1986; 19:771-774.

16. Boonkaewwan C., Toskulako C. and Vongsakul M.J. AntiInflammatory and Immunomodulatory Activities of Stevioside and Its metabolite Steviol on THP-1 Cells, J Agric Food Chem 2007; 20:323-329.

17. Chan P., Xu D.Y., Liu J.C., Chen Y.J, Tomlinson B., Huang W.P. and Cheng J.T. The effect of stevioside on blood pressure and plasma catecholamines in spontaneously hypertensive rats, Life Sci 1998; 63:1679-1684.

18. Melis M.S. Chronic administration of aqueous extract of Stevia rebaudiana in rats: renal effects, J Ethnopharmacol 1995; 47:129-134.

19. Takahashi L., Melges E. and Carneiro J. W. P. Germination performance of seeds of Stevia rebaudiana under different temperatures. Rev. Bras. Sementes 1996; 18:69.

20. Megeji N.W., Kumar J.K., Virendra Singh, Kaul V.K. and Ahuja P.S. Introducing Stevia rebaudiana-A natural Zero calorie Sweetener; Current Science 2005; 88(5). 